\title{
Ethical Sustainability in Iranian New Towns: Case Study of Shushtar New Town
}

\author{
Mahdi Hamzenazhad ${ }^{1}$, Mohadeseh Mahmoudi ${ }^{2} \&$ Bushra Abbasi $^{1}$ \\ ${ }^{1}$ School of Architecture and Environmental Design, Iran University of Science and Technology, Islamic \\ Republic of Iran \\ ${ }^{2}$ Faculty of Design and Architecture, University Putra Malaysia, Malaysia \\ Correspondence: Mohadeseh Mahmoudi, Faculty of Design and Architecture, University Putra Malaysia, \\ Malaysia. E-mail: mohadeseh.mah@gmail.com
}

Received: May 5, 2014 Accepted: May 19, 2014 Online Published: June 25, 2014

doi:10.5539/ass.v10n13p252 URL: http://dx.doi.org/10.5539/ass.v10n13p252

\begin{abstract}
Shushtar is ancient city in Khuzestan Province at south west of Iran and is considered as a world heritage. In the early 70's, Shushtar New Town was decided to be constructed in order to answer the residential needs on new employers of Karun Agro-Industries Corporation. The project was located across the river from the old city and Kamran Diba, an Iranian well-known architect, designed this New Town for 30,000 residents. Shushtar New Town was designed in relevant with the cultural values of Iranian civilization to maintain the continuity with its regional historical background. Architect's high attention on the traditional, cultural, social and historical aspect of the project helped it to be introduced as the distinguish design of $20^{\text {th }}$ century. Yet, how was ethical sustainability emanated in the master plan of Shushtar New Town? This research aims to examine sustainability in the design priorities and current condition of Shushtar New Town, on the basis of ethical sustainability as the most integrated and comprehensive current approach of sustainable development. To reach the aim of the research, history of new towns in Iran and Shushtar New Town are described, indicators of ethical sustainability are reviewed through relevant literature in the next step and then, the design priorities and current condition of Shushtar New Town are examined on the basis of ethical sustainability. In conclusion, suggestions are presented to re-emanate ethical sustainability in Shushtar New Town, and new developments are recommended in relate with design's main and mostly neglected objectives.
\end{abstract}

Keywords: ethical sustainability, sustainable relations, design priorities, Shushtar new town, Iran new towns

\section{Introduction}

Modern urbanization in Iran started from early 20s (Athari, 1991). It was after the governmental land reformation actions which the cities faced major population growth because of factors like improving health services, higher quality of living and more job opportunities. The mentioned factors were all in relate with the sudden increase in the international price of oil, followed by the higher income of the whole country which was unwisely restricted to flow only in the metropolises. The peak point of this immigration was during 1978 and 1979 when about $47 \%$ of the population growth of cities was due to immigration of villagers (Arjmand Nia, 1990). The population of Iranian Cities, and mainly the metropolises, were therefore doubled in less than two decades. As a result, the originality, identity and the quality of life of new citizens and their generation was facing true crises. The solution of Iran Urbanization and Housing Ministry to overcome this problem was designing and constructing new towns in the suburb areas of metropolises.

New town or satellite city is a planned city which is usually located nearby a metropolis and accommodates the immigrants from other parts of the country who want to work in the metropolis. New towns are usually considered as a solution for over populated metropolises. In Iran, formation of new towns started at late 70s, yet, was taken under serious consideration at mid80s. Today, by having an experience of more than two decades, accurate analyses of these new towns and their impacts on the priorities of sustainable development is needed. The positive and negative points of this accountable action has to be over viewed in order to fulfil the shortcomings of new towns and to face an uprising living quality of the poor population. Accepting the ethical approach of sustainability as the most comprehensive approach described in today's literature (Becker, 2012), 
examining these new towns based on the values of ethical sustainability could present a clear view of sustainability realization in Iran's new town design.

\subsection{Different Types of New Towns in Iran}

There have been three types of new towns in Iran. New hostel cities are the first type which offer housing to the overflow population of metropolises. The employment of the citizens in these new towns is completely dependent on the metropolis nearby. Baharestan new town, which was constructed in 1997 at the boarder of Isfahan Metropolis is known as one of these towns. Second types of new towns in Iran are the cities which are aimed to attract part of the population of the metropolises and can partly answer the needs of their citizens by creating job opportunities within the new town. Yet, in most cases, these cities are not entirely independent from metropolises. Rood-Hen Pardis new town at the boarder of Tehran as the capital of country, was planned in 1989 and is considered as one of the practiced examples of this type. The third types are the cities which are known to be as industrial cities and are aimed to provide residential comfort for the workers of a certain industry or workhouse at the suburbs. New town of Siraf, at the boarder of Boushehr Metropolis, is situated in the Special Economic Zone of Persian Gulf and is considered as one of these new towns. Siraf was constructed in 2007 to serve petroleum and Gas industries of the mentioned area (Darkoosh Abedin, 1993). The common point between all three existing types of new towns in Iran is their objective to offer suitable land property and mainly housing in accordance to the financial ability of the poor, mainly workmen and labourers, who are living in hard condition with low quality of life in the metropolises.

It was in mid90s when the concept of new towns were over looked in accordance to wide researches which took place on the basis of dynamism in urbanization. It was since then when the main objective of creating a new town became in complete relation with creating a systematic complex. A complex which apart from offering a proper frame for variable activities of various people, could offer enough flexibility to adopt with the dynamic nature of urbanization (Pakdaman, 1994).

A new town should be able to create strong financial foundations for itself so that apart from providing employment for its own citizens, it could also be considered as a city full of opportunities for others. New town should own identity and pass the sense of its identity to its citizens. Organizing a certain kind of activities and limiting the objectives of the city to those activities will not end to reaching high life quality for the citizens.

Among the eighteen new towns in Iran (Nori Nezhad, 2013), Shushtar New Town is selected as the case study of this research. This new town was designed and built as an industrial city in south west of Iran and its original design managed to glow as one of the best architecture and urban design projects among Iranian new towns of $20^{\text {th }}$ century.

\section{Research Design}

\subsection{Shushtar New Town as the Case Study of Research}

In 1973, the Pahlavi dynasty in Iran initiated efforts to revitalise the economy of Shushtar, which had stagnated since the deterioration of the waterways in the 19th century, and to further develop agricultural resources in the province. Also, Karun Agro-Industries Corporation was established in Khuzestan and needed to plan a residential and urban complex for habilitation of employees and working staff. In addition to housing the employees of a firm, building a new town in the area could provide the inhabitants of the suburbs and villages around Shushtar with the possibility to find work and housing endowed with urban facilities and an optimal hygienic environment, while programming and industrially increasing the local agriculture resources- and thus enhancing the general level of the socio-economic life of the people of the region through exploitation of the local resources (Javaherian \& Diba, 2005).

Shushtar New Town is located at Khuzestan province at south west of Iran (figure 1). This new town was designed and constructed in adjacent to the ancient city of Shushtar and on the basis of traditional design priorities of Iranian urban design and architecture. It is known as one of the most successful design projects of Iran's new towns and is the only internationally introduced project which has been able to gain different notable awards in relate with its design priorities and social concerns. Design of Shushtar New Town was the winner of Aga khan Award for Architecture in 1986 and exhibited extensively in America, Germany, Italy, France and Japan. The plan of this new town has also been published in most architectural magazines around the world (Esteghlal \& Bahadori, 2013). By designing and building Shushtar New Town, Diba presented a valuable pattern for residential complexes which have their traditional and regional identity, use the sustainable and regional materials and meet the needs of modern life style. 


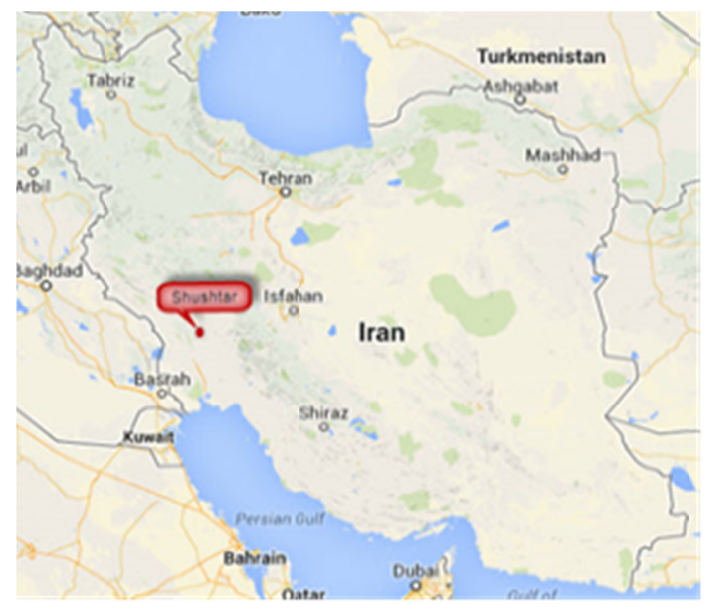

Figure 1. Shushtar new town is located at Khuzestan province in south west of Iran.

Planned in five stages, Shushtar New Town was to be completed in 1985. Construction started in 1976, and main parts of the first stage were completed by 1978 . The first stage was planned to function as autonomous unit and accommodate about 40000 inhabitants. But the political unrest and Islamic revolution in 1979 graveled the process. Villagers and war refuges became the main citizens of this new town and the condition turned out nothing as planned. Wrong organizational decisions lead to the disruption of design priorities in Shushtar New Town and the town which was awarded for its design, didn't manage to achieve its goals in practice.

In an overall view, Shushtar New Town is chosen as the case study of this research because of its adjacent with an ancient city, its traditional basis design, the attention of its designer on social and environmental concerns and the detected non-concurrency between its design and practice in the current condition. The fact that the design of Shushtar New Town is internationally known and awarded was also an important reason for its selection as the case study of this research.

\subsection{Design Priorities of Shushtar New Town}

Shushtar New Town is a residential community for 25-30 000, adjoining the old city of Shushtar in Khuzestan, southern Iran. Kamran Diba, an Iranian well-known architect and the head of D.A.Z consulting Company designed Shushtar New Town. This project was built across the Shatit River from the old city. Figure 1 shows the location of this new town in Iran. Design of this town follows the pattern of traditional Iranian architecture which is introverted, taking its forms from climatic constraints, available local technology and country's culture. The project of Shushtar New Town was a true effort to connect traditional strategies of Iranian architecture and urban design with the latest technologies of the world and modern simple geometry. Kamran Diba used traditional Iranian features and urban planning to design the Shushtar New Town. He tried his best to revive the hidden values of Iranian culture and traditional architecture of the city of Shush in Shushtar New Town. The urban plan of this new town was based on the four-fold pattern design which took four-arch pattern in its architecture from Iranian architecture and four-garden pattern from Iranian urban design. The major design feature is a multi-faceted central east west pedestrian boulevard. This consists of many gardens, paved squares, covered and shaded resting places, arcades, bazaars, pedestrian bridges completed by dramatic changes of level and decorated with lush plantations, fountains, running water and occasional use of Persian mosaic tile work. The neighbourhoods are designed to encourage movement in the direction of this pedestrian boulevard. Major public activities, such as schools, bazaars and a variety of community affairs occur along this spin (Javaherian \& Diba, 2005). The four-fold pattern of Shushtar New Town plan and its central spin is shown in figure 2.

The streets and pass-ways are not all straight and continuous. Some of them are dead-ended with variable sceneries. Wider pass-ways in residential zone of the city allows children of the neighbourhood to gather and play together. Therefore, the pass-ways are not only designed for transportation of the residents, they are in fact a very good place for local daily communications. Figure 3 shows an alley that was designed for pedestrians in the town. Indeed, designers of this town tried to provide opportunities for residents to cooperate in developing their new living environment. Several urban design researches indicate public cooperation in urban development as the creator of sense of ownership and identity in the cities (Lynch \& Hack, 1984). This could be even more essential for the new towns and their residents who are mainly immigrants and therefore, in desperate need of the mentioned senses. 

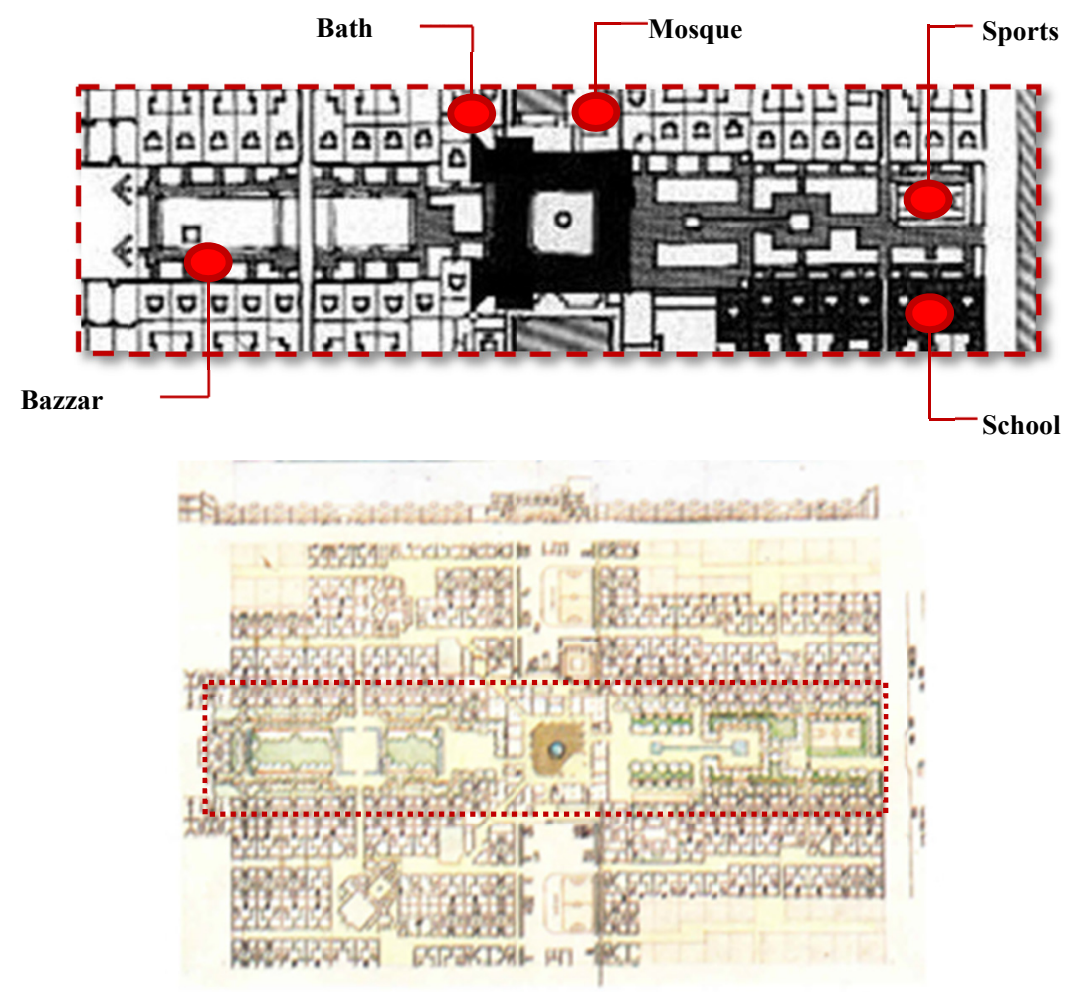

Figure 2. Site plan (Phase1) and the central spin of Shushtar New Town which is surrounded by public spaces

The covered central pass-ways of each neighbourhood creates a cool space with attractive shadows for summer walks and is a reminder of traditional Iranian bazaars. These walkways offer extra comfort in the hot summers of Shushtar for the residents besides presenting a traditional feature of Iranian urban design (figure 4). Also, in order to create beautiful and smooth urban scenery, sky line of the city is carefully designed. Shushtar New Town presents one the most successful urban designs of Iranian cities. Its example of urban housing is unique as a large scale new town conceived and produced by local designers and builders attempting to satisfy indigenous life styles and contemporary goals of industrial development.

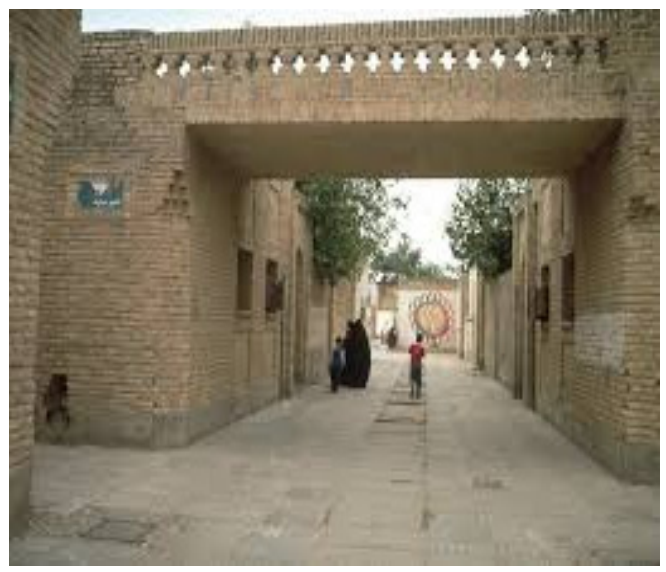

Figure 3. Pedestrian valley in Shushtar New Town

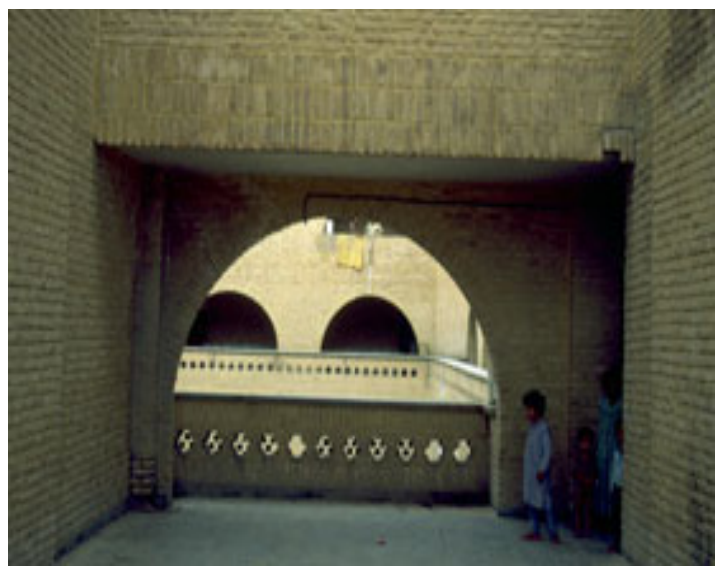

Figure 4. Covered walk-ways offer comfort to pedestrians in hot summers

\subsection{Ethical Aspect, Integrated Approach of Sustainable Development}

Sustainability has become a major topic with in the last century. It has prominently been highlighted in important global political documents such as Brundtland Report (World Commission on Environment and Development, 
1987), the Rio Declaration (United Nations, 1992a), the Agenda 21 (United Nations, 1992b), and the Johannesburg Declaration (United Nations, 2002). Ethical issues accessed in the sustainability concerns through environmental sustainability (Douglass Warner \& DeCosse, 2009) forwarded their path in social and economic approaches after being mentioned for the first time in Hanover Principles at 1996. It was there where ethics was independently introduced as a concern in internationally presented sustainable principles. In practice to obtain a more systematic approach, Becker presented in his book of "Sustainability Ethics and Sustainability Research", an integrated ethical approach of sustainability containing all three sustainability relations. He addressed his described sustainability relations on the basis of Brundtland Report about sustainable development. This report indicated promoting harmony among human beings and between humanity and nature as the aim of sustainable development strategy (World Commission on Environment and Development, 1987). Becker completes his view point by highlighting the existence of three fundamental relationships of the human being in the modern term of sustainability's true meaning. They included the relationship between humans and their contemporaries, the relationship between currently living humans and future generation and the relationship between humans and nature (Becker, 2012). The sustainable relations stated by Becker are also strongly noted in the description of sustainability presented in Brundtland Report at 1987. This report states that the humanity has the ability to make development sustainable and to ensure that it meets the needs of the present without compromising the ability of future generation to meet their own needs (Bennetts, 2003).

It is from this aspect that ethical approach in sustainable development can be called as the most integrated sustainable approach. As it is shown in figure 5, it covers all aspects of sustainability and answers the concerns of environmental, social and economic priorities of sustainable development. Therefore, can be the best paragon of analysis for examining sustainability in recent productions and developments.

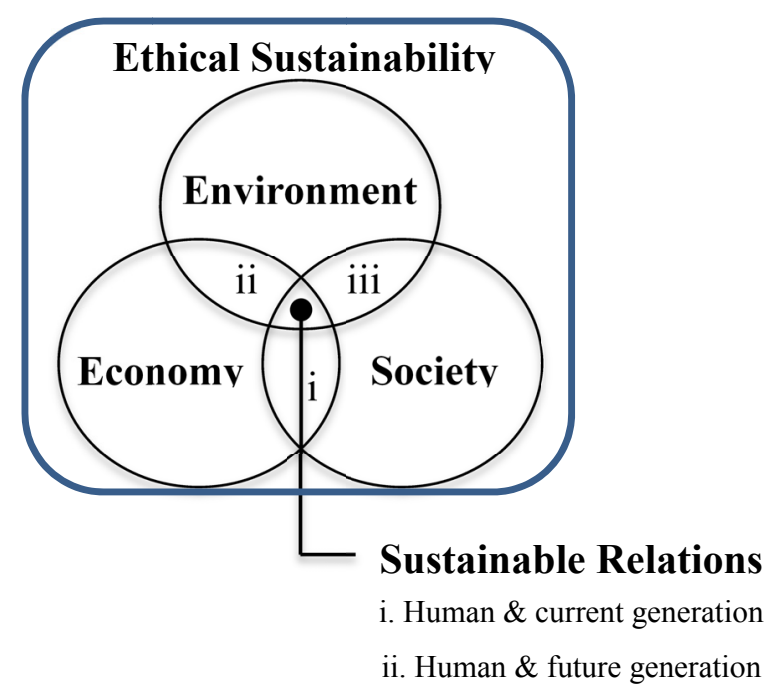

Figure 5. Ethical sustainability as an integrated approach of sustainable development

\subsection{Examining Ethical Sustainability in the Design Priorities of Shushtar New Town}

Defining ethics as synthesis of various relations on the basis of a value system (Dahl, 2012), lead ethical sustainability to describe its basis on the relationships mentioned in its foundational value system as an integrative approach of covering all aspects and relationships mentioned in sustainable development. To examine ethical sustainability in Shushtar New Town, an accurate examination of sustainability relations between human and their generation, human and future generation and human and nature is needed.

The relationship between human and their contemporaries in the design priorities of Shushtar New Town can be seen in the designer's attention on creating a central spin for the hall city and locating public spaces along it (figure 6). Wide range of open public spaces, paved squares, covered and shaded resting places, arcades, gardens and green fields are obvious connection opportunities for the citizens to spend their free time together. Directions of pass-ways, their wideness ad multifunctional utilization design besides dead ended valleys with open natural sceneries can also act as a public space for neighbourhood gatherings (figure 7). City bazaar, which plays an important role in creating relationship between humans and their contemporaries in the ancient and historical 
cities of Iran, has been designed to play the same role in the vicinity of Shushtar New Town's main spin. Locating other public places such as schools, public bath, Mosque and governmental buildings among the spin insists on even better communication among the citizens during their daily activities. In other words, the designer's effort to encourage corporation between the citizens in urban development and public gatherings on the basis of Iranian traditional urban design have ended to strengthen the relationship between citizens themselves besides their sense of identity towards their new town.

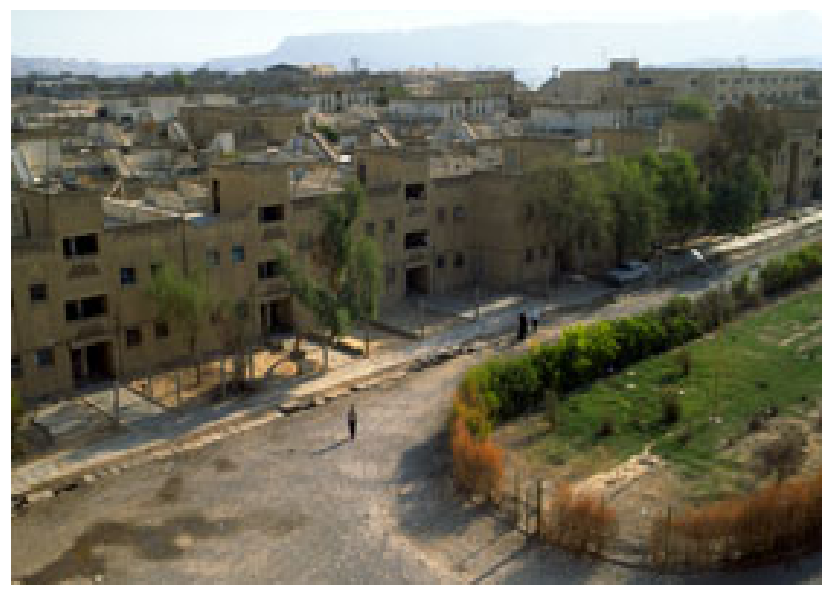

Figure 6. Central boulevard of Shushtar New Town

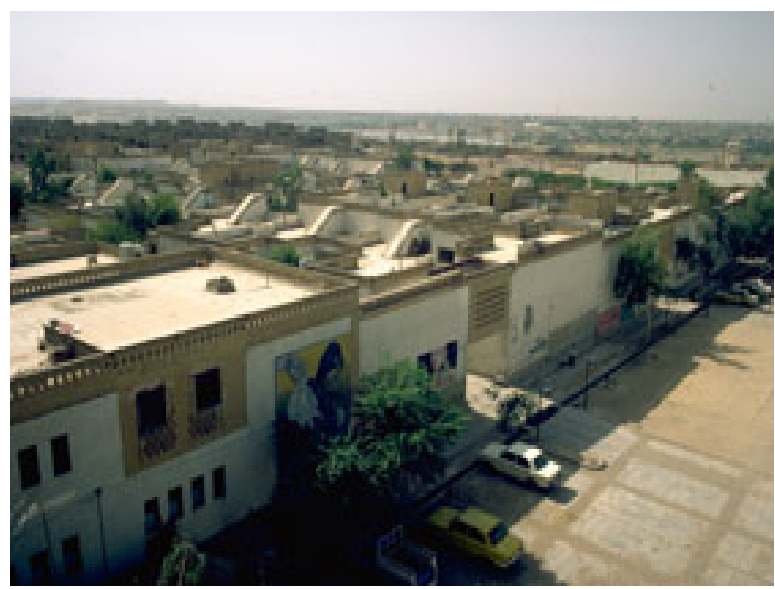

Figure 7. Wide pass-ways of Shushtar New Town

Energy saving strategies in the design of Shushtar New Town is due to the relationship between currently living humans and future generation. Using traditional features and vernacular design strategies to reach environmental comfort for the citizens plays an important role in the formation of this relationship. Designing shaded valleys alongside the bazaar and in between the residential and public spaces will provide more comfort for people in the warm months and therefore reduce the use of cooling facilities. Designing pass-ways due to the local wind direction will prevent wind dis-direction and allow natural ventilation in the residential valleys of Shushtar New Town (figure 8). Using traditional materials such as adobe bricks and simple geometrical patterns in the architectural design of the city reduces heat conversion during the sunny days (figure 9) and therefore, obtains human comfort with less energy consumption.

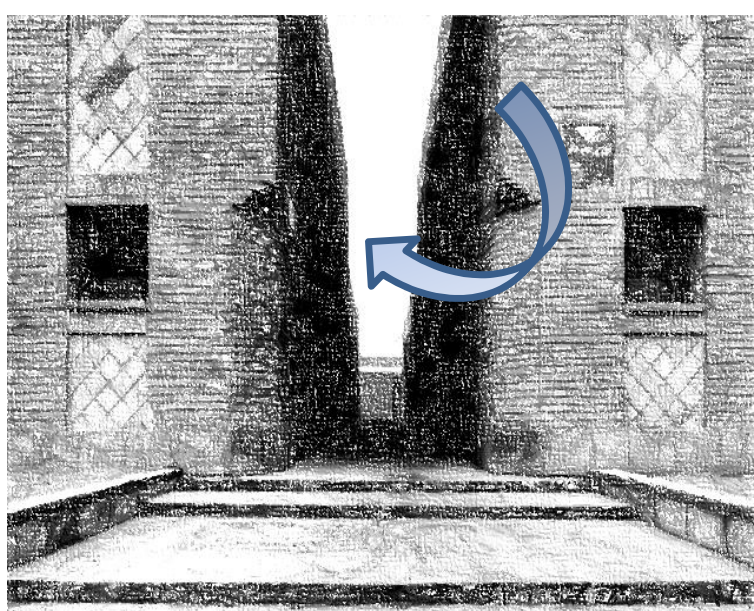

Figure 8. Climatic design of valleys allows air flow and natural ventilation through the town

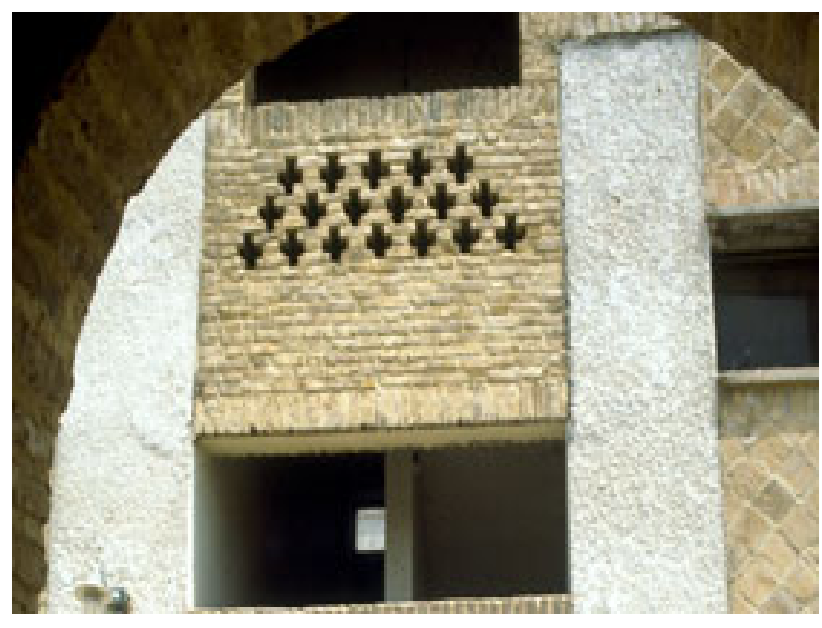

Figure 9. Vernacular architecture and use of local traditional material have decreased energy consumption in Shushtar New Town 
Main central axis of the new town, which has been called as the spin of town by its designer, is highly effective in the formation of relationship between humans and nature. This spin has been designed as continues, wide green axis adjacent with different public spaces. The idea of locating gathering spaces and public buildings around a central green spin comes from tradition urban design of Iranian cities and is due to the importance of relationship between humans and nature in traditional cities of this country. Gathering public spaces around a green axis allows citizens to enjoy a natural environment while experiencing public correlations and strengthens citizen's relationship with nature in Shushtar New Town. The designer of Shushtar New Town has tried to use traditional strategies of town design both in feature and structure, and his effort lead to a successful relationship between humans and nature in this new town. Designing the residential zone in one or two stories in order to keep the best possible scenery and a fluent sky line of the town, designing a garden, even a small one, in front of every residential building and creating a private space for residence to have their own relationship with nature is an important technique of Iranian traditional urban design in the cities of hot-arid climate (figure 10). Summing of the described relationships in Shushtar New Town is presented in table1.

Table 1. Sustainable relationships in design priorities of Shushtar New Town

\begin{tabular}{|c|c|}
\hline Sustainable relations & Design priorities of Shushtar New Town \\
\hline $\begin{array}{l}\text { Relationship between humans } \\
\text { and their contemporaries }\end{array}$ & $\begin{array}{l}\text { - Design of public axis along the town and in adjacent to public } \\
\text { buildings, bazaar and public gathering spaces. } \\
\text { - Design of wide range of open public spaces, paved squares, covered } \\
\text { and shaded resting places, arcades, gardens and green fields } \\
\text { - Design of multi-functional pass-ways and dead ended valleys }\end{array}$ \\
\hline $\begin{array}{l}\text { Relationship between currently } \\
\text { living humans and future } \\
\text { generation }\end{array}$ & $\begin{array}{l}\text { - Adaption of traditional features and vernacular design strategies } \\
\text { - Design of shaded valleys alongside the bazaar and in between the } \\
\text { residential and public spaces } \\
\text { - Adaption of traditional materials and simple geometrical patterns in } \\
\text { the architectural design } \\
\text { - Design of pass-ways due to the local wind direction }\end{array}$ \\
\hline $\begin{array}{l}\text { Relationship between humans } \\
\text { and nature }\end{array}$ & $\begin{array}{l}\text { - Design of main central axis of the new town as a green spin } \\
\text { - Climatic design of the hall town and its architecture } \\
\text { - Design of residential zone in one or two stories and keeping the best } \\
\text { possible scenery } \\
\text { - Design of private gardens for every residential unit }\end{array}$ \\
\hline
\end{tabular}

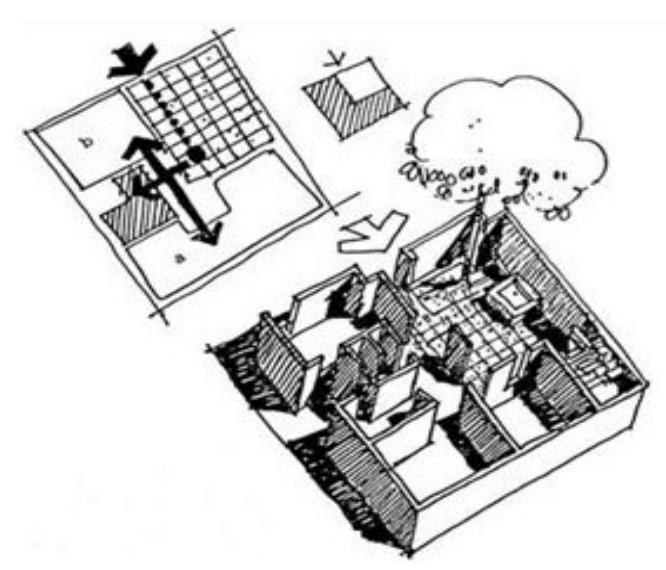

Figure 10. Designing a small private garden for every residential unit will strengthen the relationship between human and nature 


\subsection{Examining Current Conditions of Shushtar New Town}

After 30 years, an accurate overlook at Shushtar New Town is needed to evaluate the revival of its design in practice. By Islamic revolution in Iran, construction of Shushtar New Town stopped, the responsible organizations were replaced and D.A.Z. architects and planners left the country while only the first phase of project was completed. During one year of disruption in town construction, people from neighboring villages occupied some houses and a flow of war refugees faced to Shushtar New Town. They settled in not only the first phase houses, even in semi-built houses without door and windows. A report in 1986 shows that the 600 units of new town's first phase experienced a rapid over crowed. These units were designed for 4000 people, yet, three times more were inhabited that caused extra pressure on infrastructure of the town. Public spaces were abandoned and other constructions were not based on the master plan of town (Agha Khan Award for Architecture, 1986). Also, many built spaces got new functions that are shown in figure 11 and figure 12. For instance, the main boulevard that supposed to be a green walk way was turned to a big parking space (Rezaee, 2013). Sustainable relations no longer exist in Shushtar New Town because the design strategies and features which caused them have been neglected or destroyed. The valleys are no longer dead ended facing an open space for natural ventilation. The main axis has been damaged and can no longer act as the spin of Shushtar New Town. Buildings have been constructed in different levels and multi-stories have destroyed the natural scenery and the city's beautiful sky line. Figure 13 and figure14 show how the beautiful scenery of Shushtar New Town and its dead ended valleys have been ruined during the past 30 years. Old settlements have been damaged, and again repaired by un-local materials which lead to non-climatic architecture of the city. Traditional features can still be seen in the old valleys, yet are disrupted by other unrelated features and can no longer transfer the sense of identity.

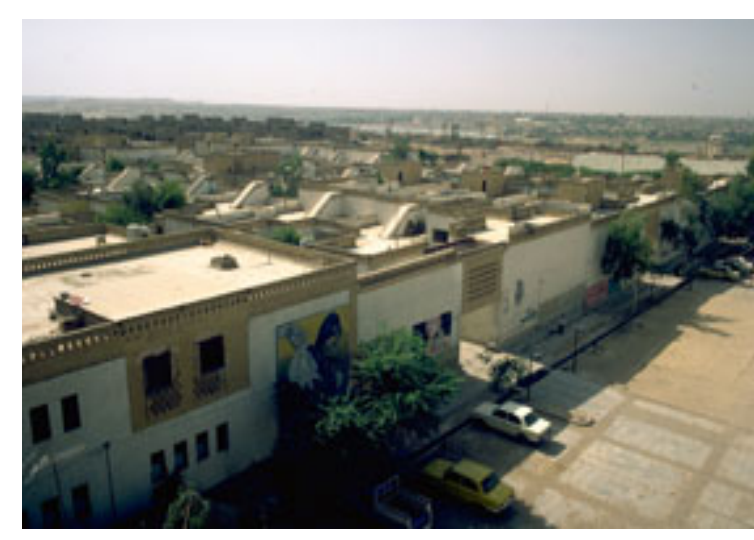

Figure 11. Green walk way has been replaced by a big parking space

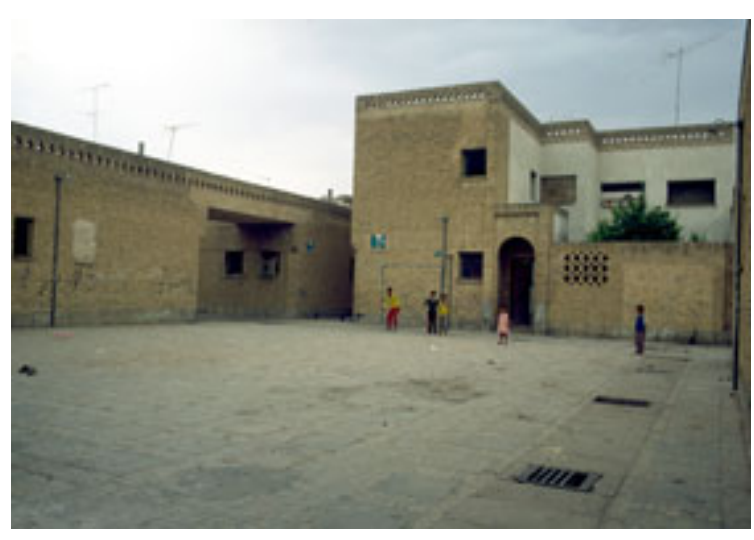

Figure 12. Space utilizations changed and green spaces in neighborhoods are destroyed

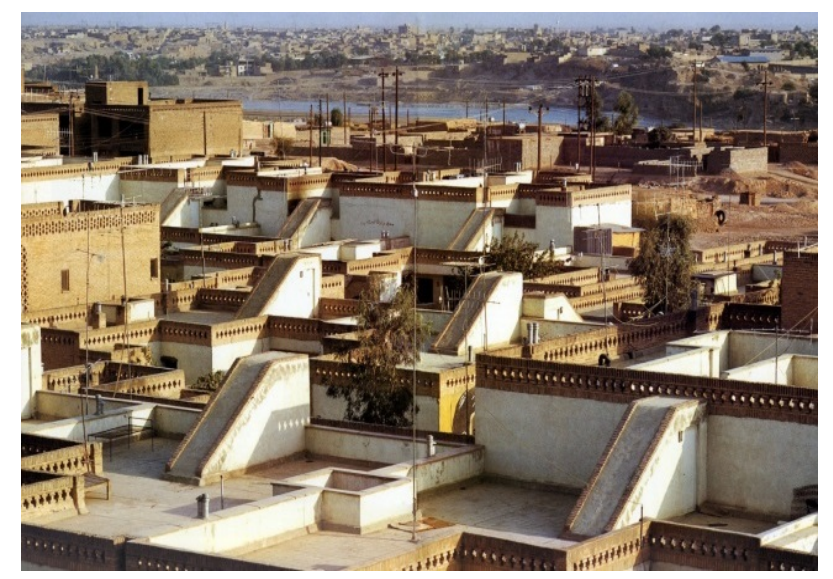

Figure 13. Bird's view of Shushtar New Town at year 1989 


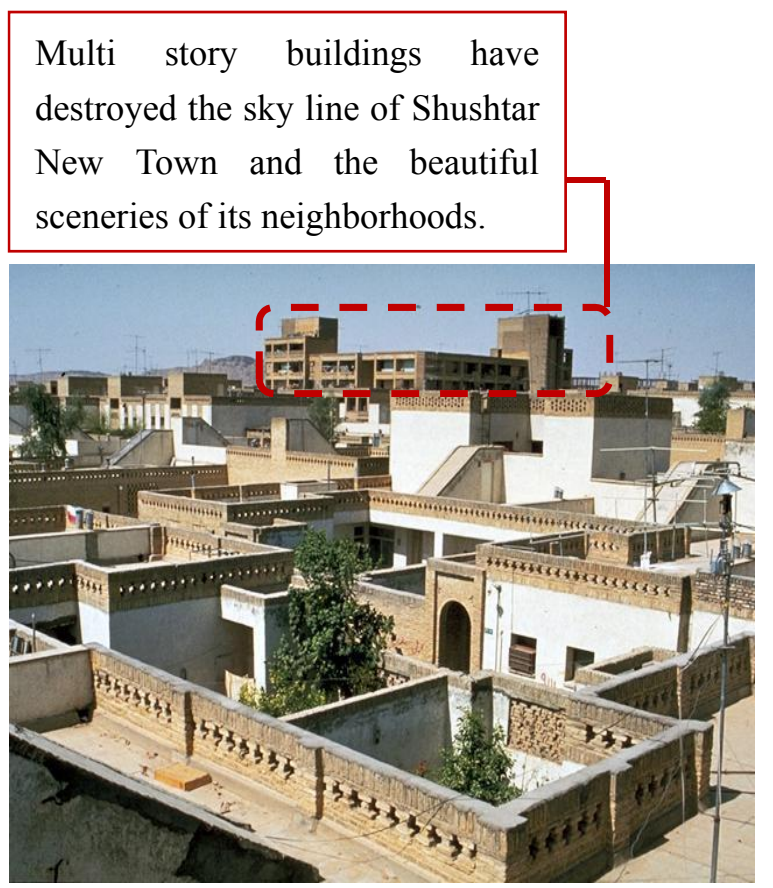

Figure 14. Bird's view of Shushtar New Town at year 2014

As it is clear, this town did not develop as it was planned for several reasons, such as political conditions of Iran at 30 years ago which caused disruption in the construction and occupation of houses by various people who unconsciously damaged the residential areas, besides the public spaces, out of their unawareness of design values in their new town (Rezaee, 2013). Wrong decision making of in charged organizations, such as constructing new buildings in the designed zone while neglecting the objectives of the master plan, was also the most important reason of damage in Shushtar New Town. Eventually, the plan of new town was disharmonized and the designed zone experienced a serious damage.

\section{Discussion and Suggestion}

During last decades, particular attention was paid to relationship between human and environment by professional experts from different fields of ecological humanism, so concepts of sustainable development were defined inclusively (Kim \& Todorovic, 2013; Naess, 2001; Thompson, 1998) but why having a sustainable building or sustainable city is still a major problem of today's development? To answer this question, some stated sustainability appraisal as an impossible fact due to rapid changes and uncertainties of today's world (Ravetz, 2000), others believes the notion of sustainable development is still vague and is considered as a confusing topic full of contradictions (Jabareen, 2008), and others pointed that this concept has not been practiced around the world very well yet (Celik, 2013).

In this study, regard to the examination of the studied area, it was found out that the design's priorities have not been fulfilled in the practice of Shushtar New Town, and therefore, it could be concluded that even though Shushtar New Town was designed in respect to the values of sustainable development and was analyzed in this research to meet the values of ethical sustainability, its constructed result in practice did not follow the named values and has not been able to create sustainable relations within its foundation. As the result of this research, Shushtar New Town in its current condition is not sustainable.

Mohamadreza Bahadori, architect and urban planner who is also a member of Shushtar Architectural Commission, believes that by registering this new town in Iran National Heritage list, there would be a hope to stop more damages forced on the urban plan of Shushtar New Town, besides the irregular constructions which are not based on the master plan and is taking place in the current timing (Esteghlal \& Bahadori, 2013). On the other hand, all the responsible authorities and organizations should be justified to follow the master plan of Shushtar New Town for further developments in the city. It is only in this case that further developments could have enough time to analyze the project and call for new studies to prepare design plans adaptable with the foundational structure of the town and its original master plan. To make this happen, Iranian Cultural Heritage 
and Tourism Organization should take its chance for registering this complex. This will not only be in the benefit of the residential parts, but it is mostly important for urban spaces to preserve the potentials of new town's context (Najafi, 2013).

In addition, during these years, different people interviewed with Kamran Diba in regards to the objectives of the design, current conditions and future of this town. Even though he had already stated this town's failure in achieving its primary objectives, he believes that it will still be possible to achieve $80 \%$ of its objectives if the responsible organizations, as decision makers, decide to prevent the town from destruction and stop this wrong process before new Shushtar becomes a slums settlements. Since this town holds extensive lands, the organizations will be able to get enough income from selling the lands to spend on the reclamation of residential areas which are mostly damaged. Financial management and inner investments can easily take place due to new town's natural potentials, yet, cooperation of Shushtar municipality is needs for integrating the management of the Shushtar New Town (Rezaee, 2013).

These discussions revealed that reclamation of this new town needs cooperation between different organizations to reach the best result as an integrated management for the town. It helps to stop chaotic construction and follow back the master plan of Shushtar New Town. Besides, it is recommended to invite the responsible professionals specially Diba and other D.A.Z corporation partners who designed this new town, hold the primary plans of the town and are eager to cooperate with new management and guide new developments.

\section{References}

Agha Khan Award for Architecture. (1986). Shushtar New Town. Retrieved April 1, 2014, from http://www.akdn.org/architecture/project.asp?id=117

Arjmand Nia, A. (1990). The role of new towns in population habitation. Journal of economical-political information, 7.

Athari, K. (1991). Development strategies, urbanism strategies and new towns. Journal of economical-political information, 1.

Becker, C. U. (2012). Sustainability ethics and sustainability research. New York: Springer.

Bennetts, H. (2003). Understanding sustainable architecture. London: Taylor \& Francis.

Celik, B. G. (2013). Exploring sustainable developmentt and its interpretation in the built environment. Journal of Sustainable Development, 6(12), 83-91.

Dahl, A. L. (2012). Achievements and gaps in indicators for sustainability. Ecological Indicators, 17(0), 14-19. http://dx.doi.org/10.1016/j.ecolind.2011.04.032

Darkoosh Abedin, S. (1993). An Introduction to Urban Economics. Tehran: Nashre Daneshgahi press.

Douglass Warner, K., \& DeCosse, D. (2009). Lesson four: The ethical dimensions of sustainability. Retrieved from http://www.scu.edu/ethics/practicing/focusareas/environmental_ethics/lesson4.html

Esteghlal, A., \& Bahadori, M. (2013). Shushtar Now. Honar-e Memari Magazine, 25.

Jabareen, Y. (2008). A new conceptual framework for sustainable development. Environment, development and sustainability, 10(2), 179-192.

Javaherian, F., \& Diba, K. (2005). Shushtar New Town. In I. Eetesam (Ed.), New Towns (pp. 15-36). Tehran: New Towns Development Sooperation.

Kim, J. T., \& Todorovic, M. S. (2013). Towards sustainability index for healthy buildings-Via intrinsic thermodynamics, green accounting and harmony. Energy and Buildings, 62(0), 627-637. http://dx.doi.org/10.1016/j.enbuild.2013.03.009

Lynch, K., \& Hack, G. (1984). Site Planning. United States of America: The MIT Press.

Naess, P. (2001). Urban planning and sustainable development. European Planning Studies, 9(4), 503-524.

Najafi, H. (2013). Interview with Mohammadreza Bahadori about Shushtar Now. Honar-e Memari, 25.

Nori Nezhad, A. (2013). Assessment of new towns in Iran based on built new towns after Islamic revolution. Retrieved from http://saman.hic-iran.com/fa/article/42

Pakdaman, N. (1994). The story of development thinking. In J. -J. Salomon, F. R. Sagasti, \& C. Sach-Jeantet (Eds.), The Uncertain Quest: Science, Technology, and Development (pp. 65-95). Tokyo, Paris, New York, NY.: United Nations University Press. 
Ravetz, J. (2000). Integrated assessment for sustainability appraisal in cities and regions. Environmental Impact Assessment Review, 20, 31-64.

Rezaee, T. (2013). Failure of Shushtar Now, an instructive experience. Honar-e Memari Magazine.

Thompson, I. H. (1998). Environmental ethics and the development of landscape architectural theory. Landscape Research, 23(2), 175-194. http://dx.doi.org/10.1080/01426399808706534

United Nations. (1992a). Rio declaration on environment and development. New York: United Nations.

United Nations. (1992b). Agenda 21. New York: United Nations.

United Nations. (2002). Johannesburg declaration on sustainable development. New York: United Nations.

World Commission on Environment and Development. (1987). Our common future. Oxford: oxford University Press.

\section{Copyrights}

Copyright for this article is retained by the author(s), with first publication rights granted to the journal.

This is an open-access article distributed under the terms and conditions of the Creative Commons Attribution license (http://creativecommons.org/licenses/by/3.0/). 